\title{
Ekuitas Merek dan Loyalitas Pelanggan
}

\author{
Arif Rakhman \\ Fakultas Ekonomi dan Bisnis, Universitas Singaperbangsa Karawang \\ Email: arif.rakhman@fe.unsika.ac.id
}

\begin{abstract}
The purpose of this research are to determine the influence of staff service, self-image congruence, and brand awareness on brand satisfaction and attitudinal loyalty, and the influence of brand satisfaction on attitudinal loyalty in three star hotels at Tegal. By using non-probability sampling, this research uses 120 respondents to be the sample. This study uses Structural Equation Modeling (SEM) Sub-Group. The results of this study are staff service, self-image congruence, and brand awareness have significant influence on brand satisfaction and attitudinal loyalty, brand satisfaction has significant influence on attitudinal loyalty.
\end{abstract}

Keywords: Staff service, self-image congruence, brand awareness, brand satisfaction, attitudinal loyalty

\section{Pendahuluan}

Industri perhotelan saat ini telah diakui sebagai industri global dengan produsen dan konsumen yang tersebar di seluruh dunia. Penggunaan fasilitas hotel seperti: kamar, restoran, bar, klub malam atau klub kesehatan; tidak lagi dianggap sebagai barang mewah. Bagi banyak orang, layanan ini telah menjadi komponen integral dari gaya hidup. Selain itu, dalam dua dekade terakhir, permintaan dan pasokan layanan perhotelan di luar layanan tradisional yang ditujukan untuk pelancong telah meningkatkan pertumbuhan industri perhotelan secara global, yang mengarah ke persaingan yang ketat di pasar. Salah satu tantangan terbesar yang dihadapi pengusaha hotel saat ini adalah volume dan laju kompetisi yang terus tumbuh (Kandampully \& Suhartanto, 2000).

Secara historis, manajemen merek belum menjadi perhatian utama pelaku bisnis perhotelan. Dalam beberapa dekade terakhir, situasi ini telah sangat berubah. Manajemen merek tampaknya menjadi salah satu bidang perhatian dan penelitian yang berkembang paling pesat. Dalam lingkungan bisnis yang kompetitif saat ini, mengelola ekuitas merek telah menjadi 
penting bagi organisasi perhotelan (Ahmad \& Hashim, 2011).

Konsep dan pengukuran ekuitas merek di industri perhotelan telah mendapat perhatian besar dari akademisi, praktisi, dan peneliti dalam beberapa tahun terakhir (Bailey \& Ball, 2006). Berbagai alasan telah dikutip dalam literatur untuk pertumbuhan branding dalam industri perhotelan. Dari sudut pandang konsumen, manfaat utamanya termasuk mengurangi risiko yang dirasakan dan mengurangi biaya pencarian. Sedangkan dari sudut pandang pemilik merek, argumen utama yang diusulkan adalah sebagai kemampuan untuk membebankan harga premium di atas hotel pesaing, kemampuan untuk mendapatkan pangsa pasar, dan kemampuan untuk mempertahankan pelanggan dengan membangun loyalitas merek yang pada gilirannya dapat mengurangi biaya pemasaran (Sangster, Wolton, \& Day, 2001).

O'Neill dan Matilla (2004) juga menunjukkan bahwa merek dengan tingkat kepuasan yang tinggi, tampaknya tidak hanya mencapai pendapatan yang besar, tetapi juga mencapai tingkat pertumbuhan pendapatan yang lebih tinggi daripada merek dengan kepuasan yang lebih rendah. Terlepas dari minat ini, literatur yang ada tentang ekuitas merek dalam industri hotel masih jarang. Ada kesenjangan (gap) dalam literatur ekuitas merek tentang apa yang dimaksud dengan ekuitas merek hotel, dari perspektif mana ia harus dilihat, dan bagaimana itu harus dioperasikan.

Penelitian ini bertujuan untuk memberikan kontribusi terhadap teori layanan ekuitas merek dan khususnya literatur ekuitas merek hotel yang sangat terbatas. Karena kurangnya data empiris di wilayah yang diteliti (Kim \& Kim, 2005), studi ini memberikan informasi berharga untuk operasional komponen ekuitas merek berbasis pelanggan dan bagaimana mereka berinteraksi satu sama lain dalam sistem industri perhotelan. Hasil akhir dari penelitian ini juga harus mengarah pada pemahaman yang lebih baik dalam konsep ekuitas merek hotel.

Loyalitas telah menjadi penting selama beberapa tahun terakhir karena meningkatnya persaingan dalam industri. "Loyalitas" memiliki makna yang sama dengan mengembangkan upaya pemasaran dan periklanan strategis dalam menciptakan hubungan antara perusahaan dengan pelanggannya. Dalam mewujudkan daya saing berkelanjutan yang akan terjadi dalam industri, banyak perusahaan perhotelan mengalihkan fokus mereka ke pemasaran hubungan, khususnya melalui konsep loyalitas. Dengan meningkatnya daya tawar yang diperoleh konsumen, perusahaan perhotelan menyadari kunci keberhasilan mereka adalah untuk menumbuhkan 
upaya pemasaran hubungan strategis, terutama melalui penggunaan langkah-langkah loyalitas (Liang, 2008).

Sebagai pemilik, penting untuk menawarkan produk atau layanan yang memungkinkan keberlanjutan hotel. Pada saat yang sama, penting untuk mengetahui tamu-tamu yang berlangganan hotel. Mengetahui kebutuhan dan permintaan mere$\mathrm{ka}$, dan memanfaatkan informasi ini untuk tujuan implementasi produk atau layanan yang akan menuju upaya keberlanjutan dan penciptaan loyalitas jangka panjang. Penting juga untuk memberikan perhatian yang besar pada efisiensi fasilitas dan layanan yang disediakan. Pelanggan mengharapkan layanan dilakukan dengan cara yang membantu (Liang, 2008). Gold (2005) mengesahkan keyakinan yang melekat dan juga membahas bagaimana kepuasan dan kenyamanan instan sangat penting dari perspektif pelanggan.

Pelayanan staf (Staff service) sangat penting dalam menentukan kualitas pelayanan, dan secara signifikan berkontribusi terhadap pembentukan kepuasan pengunjung dengan ekuitas merek hotel yang mengarah pada loyalitas merek. Pelayanan staf yang terlatih, dapat menghasilkan pelayanan yang sangat baik bagi pelanggan dan merupakan aset yang sangat berharga bagi penyedia pelayanan. Konsekuensinya, pelayanan staf yang terlatih akan memberikan pengalaman yang tak terlupakan (Ahmad \& Hashim, 2011). Kesesuaian citra-diri (Self-image congruence), yang melibatkan perbandingan psikologis, telah digunakan untuk memprediksi kepuasan dalam beberapa situasi. Dapat dipahami bahwa kesesuaian citra-diri mempengaruhi perilaku pembelian melalui motif pelanggan. Pelanggan meningkatkan kepuasan mereka ketika merasakan kesesuaian citra tingkat tinggi. Hal ini juga mengarahkan organisasi bisnis untuk memposisikan diri. Kesesuaian citra diri yang tinggi mengarah pada loyalitas merek. Dalam hal ini, kesesuaian citra-diri memperkuat merek yang dikaitkan dengan citra pengguna, yang akhirnya mengarah pada loyalitas merek (Ahmad \& Hashim, 2011).

Konstruk penting lainnya adalah kesadaran merek konsumen yang terkait dengan representasi kognitif merek dan kinerja organisasi. Dengan demikian, ada baiknya untuk memeriksa bagaimana dimensi ekuitas merek mempengaruhi dan memprediksi perilaku, yang pada gilirannya akan kembali sebagai pelanggan yang loyal. Meskipun peneliti memiliki pandangan yang berbeda tentang hubungan kepuasan-sikap, mereka menyarankan bahwa kesadaran merek yang kuat secara positif mempengaruhi kepuasan merek untuk membentuk sikap yang mengun- 
tungkan. Jalur yang diusulkan juga didukung oleh studi sebelumnya dalam setting perhotelan, khususnya di penginapan dan restoran cepat saji. Dengan demikian, penelitian ini berspekulasi bahwa kesadaran merek dapat menghasilkan kepuasan merek melalui keakraban merek (Ahmad \& Hashim, 2011).

Kepuasan keseluruhan, berbeda dari kepuasan transaksi spesifik, dibentuk oleh proses penilaian evaluatif pengalaman pasca konsumsi. Penelitian pasar terapan lebih cenderung mendasarkan kepuasan pelanggan pada tingkat kepuasan keseluruhan dengan berbagai aspek perusahaan daripada kepuasan episode spesifik. Kepuasan merek dalam penelitian ini mengoperasikan kepuasan keseluruhan terhadap merek berdasarkan pengalaman sebelumnya. Kepuasan mengarah pada komitmen dalam pertukaran relasional bisnis-kebisnis karena hubungan yang ditandai dengan kepuasan sangat dihargai sehingga pihak-pihak ingin berkomitmen pada hubungan semacam itu kemudian meningkatkan niat kehadiran berulang untuk loyalitas merek pada sikap merek (Ahmad \& Hashim, 2011).

Tegal memiliki lokasi yang strategis, karena terletak di jalan pantai utara (Pantura) Jawa Tengah, dan memiliki persimpangan jalan utama yang menghubungkan pantura dengan kota-kota di Pulau
Jawa bagian selatan. Tegal terletak antara Jakarta dan Surabaya. Posisi strategis yang didukung oleh infrastruktur yang baik menjadikan Tegal sebagai kota transit. Hal ini berdampak pada kehidupan bisnis di bidang layanan pariwisata, tidak terkecuali industri perhotelan.

Perdagangan dan jasa adalah sektor ekonomi utama kota Tegal. Iklim investasi yang baik mengundang lebih banyak investor luar untuk menginvestasikan uang mereka di kota ini. pada sektor jasa, dalam 15 tahun terakhir sejak tahun 2001, beberapa hotel bintang telah dibangun seperti Hotel Bahari Inn, Karlita International Hotel, Plaza Hotel, dan Riez Palace. Selain itu, banyak kelas melati hotel meramaikan industri hotel di Tegal.

Selain hotel-hotel yang disebutkan di atas, ada beberapa hotel berbintang yang akan dibangun untuk bersaing dalam industri perhotelan di Tegal. Perkembangan industri perhotelan di Tegal tidak lepas dari banyaknya kunjungan wisatawan asing dan domestik ke Tegal. Berdasarkan data pemerintah Kota Tegal tahun 2014, jumlah turis asing yang mengunjungi Tegal adalah 2.051 orang (1\%) sedangkan untuk wisatawan domestik 257.446 orang (99\%). Oleh karena itu, industri perhotelan memberikan kontribusi yang cukup di sektor ekonomi Tegal. Karena tingginya persaingan di Tegal, maka setiap hotel 
harus memberikan penetrasi merek dan mempertahankan ekuitas mereknya untuk menarik pelanggan baru dan mempertahankan loyalitas pelanggan. Hotel-hotel harus melihat faktor-faktor yang dapat memenangkan persaingan. Faktor-faktor yang dapat dipertimbangkan oleh hotel

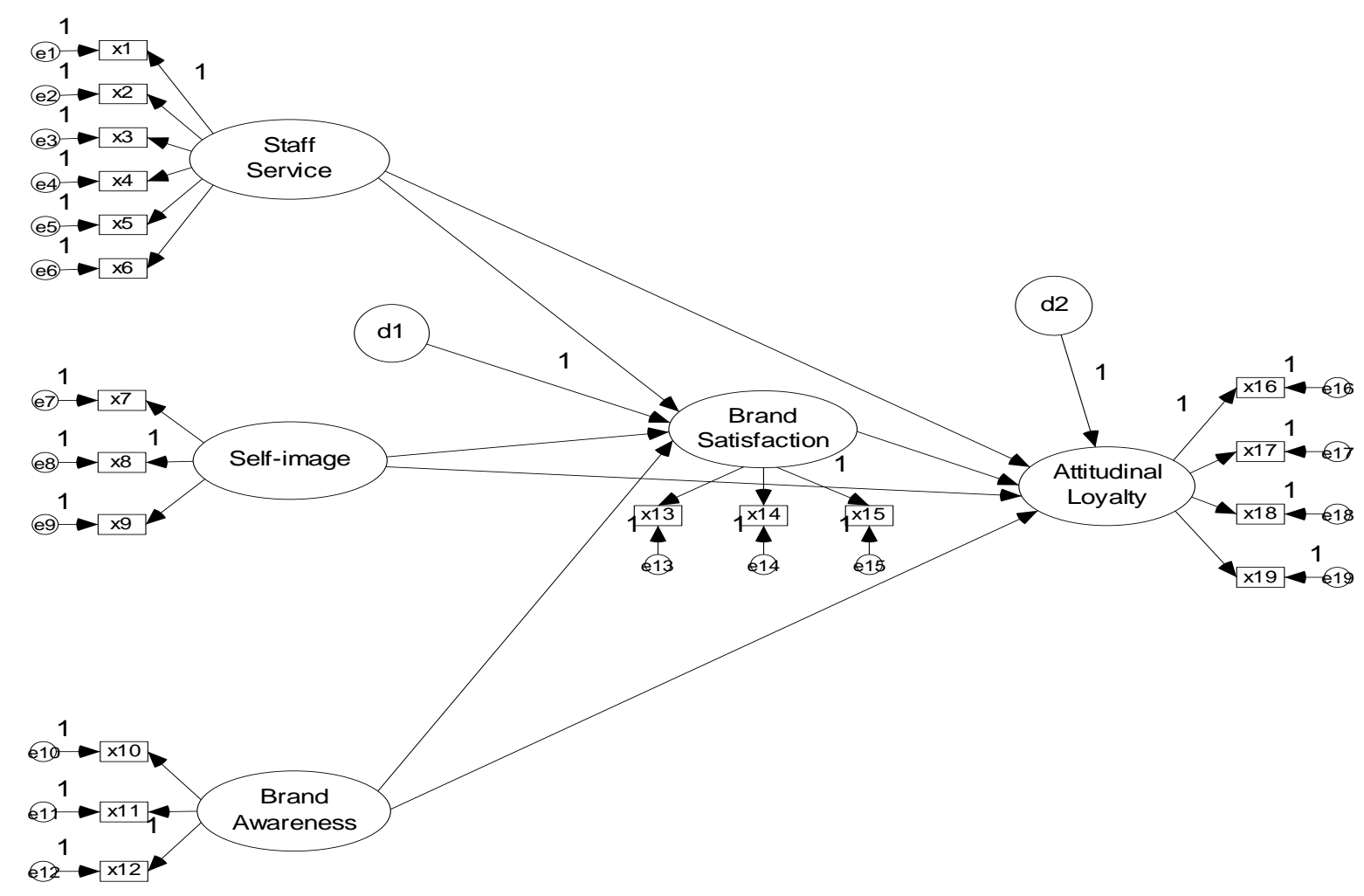

Gambar 1. Model Pengukuran adalah: memberikan layanan berkualitas dengan layanan staf terbaiknya, memberikan kesesuaian citra diri dan kesadaran merek kepada pelanggan agar pelanggan merasa puas dan menjadi pelanggan setia. Akhirnya, hotel dapat memimpin pangsa pasar dan memenangkan persaingan.

\section{Kerangka Pemikiran dan Hipotesis}

Berdasarkan penjelasan di atas, peneliti merumuskan hipotesis sebagai berikut: H1 : Pelayanan staff berpengaruh signifykan pada kepuasan merek pelanggan hotel bintang tiga

H2 : Pelayanan staff berpengaruh signifikan pada sikap loyalitas pelanggan hotel bintang tiga
H3 : Citra-diri berpengaruh signifikan pada kepuasan merek pelanggan hotel bintang tiga

H4 : Citra-diri berpengaruh signifikan pada sikap loyalitas pelanggan hotel bintang tiga

H5 : Kesadaran merek berpengaruh signifikan pada kepuasan merek pelanggan hotel bintang tiga 
H6 : Kesadaran merek berpengaruh signifikan pada sikap loyalitas pelanggan hotel bintang tiga

H7 : Kepuasan merek berpengaruh signifikan pada sikap loyalitas pelanggan hotel bintang tiga

\section{Metode Penelitian}

Penelitian ini adalah penelitian kuantitatif dengan menggunakan metode survei. Penelitian ini dilakukan di hotel bintang tiga di Tegal. Hotel-hotel tersebut adalah Karlita International Hotel, Hotel Bahari Inn, dan Riez Palace Hotel. Sebenarnya ada empat dari tiga hotel berbintang di Tegal, tetapi hanya tiga hotel yang menyetujui untuk menjadi objek penelitian. Jadi, penelitian dilakukan di tiga hotel.

Penentuan sampel menggunakan rumus Slovin (Umar, 2008).

$$
n=\frac{N}{1+N e}
$$

Di mana :

$\mathrm{n} \quad=$ ukuran sampel

$\mathrm{N}=$ ukuran populasi

e $\quad=$ persentase kesalahan yang dapat ditoleransi (10\%)

Menurut manajer hotel, populasi pelanggan hotel bintang tiga di setiap hotel setiap hari adalah sebagai berikut:

Karlita International Hotel $=90$ kamar $\mathrm{x}$ $45 \%=40,5 \times 2$ people $=81$

Hotel Bahari Inn $=80$ kamar $\mathrm{x} 40 \%=32 \mathrm{x}$ 2 people $=64$
Riez Palace Hotel $=91$ kamar $\mathrm{x} 40 \%=$ $36,4 \times 2$ people $=72,8 \infty 72$

Total populasi dalam 1 bulan $=81+$ $64+72=217 \times 30=6510$ digunakan untuk menentukan jumlah sample adalah:

$$
\begin{aligned}
& n=\frac{N}{1+\left(N x e^{2}\right)} \\
& n=\frac{6510}{1+\left(6510 \times 0,10^{2}\right)} \\
& n=98,48 \quad \infty 98
\end{aligned}
$$

Berdasarkan pada perhitungan, sampel minimum adalah 98 responden. Namun, untuk meningkatkan akurasi, sampel yang diambil dalam penelitian ini adalah 120 responden.

Pengambilan sampel dilakukan dengan menggunakan non-probability sampling. Non-probability sampling adalah teknik yang tidak memberikan peluang yang sama untuk elemen yang dipilih ke dalam populasi sampel. Sedangkan teknik yang digunakan adalah accidental sampling. Accidental sampling adalah teknik pengambilan sampel berdasarkan aksidental. Artinya, sampel adalah anggota populasi yang ditemui oleh peneliti dan bersedia menjadi responden.

Jenis data dalam penelitian ini menggunakan data primer dan teknik pengumpulan data menggunakan kuesionair. 
Table 1. Standardized Regression Weight Results

\begin{tabular}{lllrl}
\hline & & & C.R. & t table \\
\hline Brand_Satisfaction & $<---$ & Staff_Service & 2.624 & 1.960 \\
Attitudinal_Loyalty & $<---$ & Staff_Service & 3.462 & 1.960 \\
Brand_Satisfaction & $<---$ & Self-image & 2.996 & 1.960 \\
Attitudinal_Loyalty & $<---$ & Self-image & 3.233 & 1.960 \\
Brand_Satisfaction & $<---$ & Brand_Awareness & 3.125 & 1.960 \\
Attitudinal_Loyalty & $<---$ & Brand_Awareness & 3.028 & 1.960 \\
Attitudinal_Loyalty & $<---$ & Brand_Satisfaction & 2.250 & 1.960 \\
\hline
\end{tabular}

\section{Pembahasan dan Hasil}

Asumsi yang harus dipenuhi dalam prosedur pengumpulan dan pengolahan data yang dianalisis oleh SEM harus memenuhi beberapa kriteria seperti: ukuran sampel, normalitas data, outliers, multikolinieritas, dan singularitas.

Sedangkan ukuran sampel yang harus dipenuhi dalam SEM minimal 100 selanjutnya menggunakan perbandingan lima observasi untuk setiap parameter.

Critical ratio value atau $\mathrm{CR}$ adalah \pm 2,58 pada tingkat signifikan 0,01 (1\%), dapat disimpulkan bahwa tidak ada data yang bias, sehingga data yang digunakan dalam penelitian ini adalah layak karena hamper seluruh data ada pada rentang nilai kurang dari 2,58.

Observasi yang memiliki z-score > $\pm 3,0$ akan dikategorikan sebagai outliers. Data yang digunakan dalam penelitian ini adalah bebas dari outlier univariate, karena tidak ada variable yang memiliki $z$ score lebih dari batas angka.

Rentang perhitungan mahalanobis di dasarkan pada nilai Chi-square dalam distribusi table $\mathrm{X}^{2}$ dengan jumlah variabel sebanyak 19 pada level $\mathrm{p}<0.001$ adalah $(19 ; 0.001=43.820)$. oleh karena itu, data yang memiliki rentang mahalanobis lebih besar dari 43.820 termasuk multivariate outliers. Tetapi dalam analisis ini, outliers yang ditemukan tidak akan dihilangkan dari analisis karena data menggambarkan situasi sebenarnya dan tidak ada alasan khusus dari profil responden yang menyebabkan data harus dieliminasi (Ferdinand, 2002).

Dalam penelitian ini, nilai determinan sebesar 0.050. Angka tersebut lebih besar dari nol sehingga dapat disimpulkan bahwa tidak ada multicollinearitas dan singularitas, data dalam penelitian ini layak untuk digunakan. 
Reliabilitas adalah ukuran tentang konsistensi internal dari indikator konstruk yang menunjukkan sejauh mana masingmasing indikator menunjukkan konstruk umum (Ferdinand, 2000). Dalam SEM, batas nilai yang digunakan untuk menilai tingkat realibilitas yang dapat diterima adalah $>0.70$.

Perhitungan uji reliabilitas dalam penelitian ini menggunakan rumus di bawah ini (Ferdinand, 2002):

$$
\text { Variance Extract }=\frac{\sum \text { Std. Loading }{ }^{2}}{\sum \text { Std. Loading }{ }^{2}+\sum \varepsilon_{j}}
$$

Variance Extract adalah ukuran yang menunjukkan jumlah varian dari indicator yang diekstrasi oleh konstruk laten yang dikembangkan (Ferdinand, 2000). Nilai variance extract yang tinggi menunjukkan bahwa indikator-indikator dari variabel laten telah dikembangkan dengan baik. Dalam SEM, nilai yang digunakan untuk mengukur variance extract yang diterima adalah > 0.50 (Ferdinand, 2000).

Perhitungan variance Extract dalam penelitian ini menggunakan rumus sebagai berikut (Ferdinand, 2002):

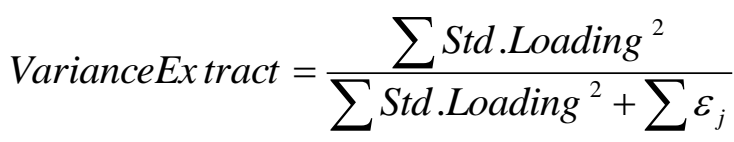

Untuk menguji hipotesis dapat diterima atau ditolak, perlu membandingkan hubungan antara nilai coefficient regression (CR) dengan nilai $\mathrm{t}_{\text {table }}$.
Penjelasan mengenai hasil pengujian hipotesis berdasarkan pada table 1 adalah sebagai berikut:

1. Pengaruh Pelayanan Staff terhadap Kepuasan Merek

Nilai C.R untuk pengaruh variabel pelayanan staff terhadap kepuasan merek adalah lebih besar dari nilai $t_{\text {tabel }}$, C.R > $t_{\text {tabel }}(2.624>1.960)$. Oleh karena itu, hipotesis nol bahwa regression weight sama dengan nol dapat ditolak dan hal ini berarti pengaruh pelayanan staff terhadap kepuasan merek adalah signifikan, sehingga hipotesis pertama yang menyatakan pelayanan staff memiliki pengaruh signifikan terhadap kepuasan merek pelanggan hotel bintang tiga di Tegal diterima.

2. Pengaruh Pelayanan Staff terhadap Sikap Loyalitas

Nilai C.R untuk pengaruh variabel pelayanan staff terhadap sikap loyalitas adalah lebih besar dari nilai $t_{\text {tabel }}$, C.R > $t_{\text {tabel }}(3.462>1.960)$. Oleh karena itu, hipotesis nol bahwa regression weight sama dengan nol dapat ditolak dan hal ini berarti pengaruh pelayanan staff terhadap sikap loyalitas adalah signifikan, sehingga hipotesis kedua yang menyatakan pelayanan staff memiliki pengaruh signifikan terhadap sikap loyalitas pelanggan hotel bintang tiga di Tegal diterima. 
3. Pengaruh Citra-Diri terhadap Kepuasan Merek

Coefficient regression secara signifikan tidak sama dengan nol, hal ini ditunjukkan oleh nilai C.R yang lebih besar dari nilai $t_{\text {tabel }}(2.996>1.960)$, oleh karena itu, hipotesis nol bahwa regression weight sama dengan nol dapat ditolak dan pengaruh hubungan dalam model diterima, sehingga hipotesis ketiga yang menyatakan citra-diri memiliki pengaruh signifikan terhadap kepuasan merek pelanggan hotel bintang tiga di Tegal diterima.

4. Pengaruh Citra-Diri terhadap Sikap Loyalitas

Nilai C.R dan nilai $t_{\text {tabel }}$ terlihat bahwa C.R > $t_{\text {tabel }}(3.233>1.960)$. oleh karena itu, hipotesis nol yang menyatakan regression weight sama dengan nol dapat ditolak dan pengaruh hubungan dalam model diterima, sehingga hipotesis ke empat yang menyatakan citra-diri memiliki pengaruh signifikan terhadap sikap loyalitas pelanggan hotel bintang tiga di Tegal diterima.

5. Pengaruh Kesadaran Merek terhadap Kepuasan Merek

Nilai C.R dan nilai $t_{\text {tabel }}$ terlihat bahwa C.R > $t_{\text {tabel }}(3.125>1.960)$. oleh karena itu, hipotesis nol yang menyatakan regression weight sama dengan nol dapat ditolak dan pengaruh hubungan dalam model diterima, sehingga hipotesis kelima yang menyatakan bahwa kesadaran merek memiliki pengaruh signifikan terhadap kepuasan merek pelanggan hotel bintang tiga di Tegal diterima.

6. Pengaruh Kesadaran Merek terhadap Sikap Loyalitas

Nilai C.R untuk variabel kesadaran merek terhadap sikap loyalitas lebih besar dari nilai $t_{\text {tabel }}(3.028>1.960)$, oleh karena itu hipotesis nol bahwa regression weight sama dengan nol dapat ditolak dan hal ini berarti pengaruh kesadaran merek terhadap sikap loyalitas juga signifikan, sehingga hipotesis keenam yang menyatakan kesadaran merek memiliki pengaruh signifikan terhadap sikap loyalitas pelanggan hotel bintang tiga di Tegal diterima.

7. Pengaruh Kepuasan Merek terhadap Sikap Loyalitas

Nilai C.R untuk pengaruh variabel kepuasan merek terhadap sikap loyalitas lebih besar dari nilai $t_{\text {tabel }}(2.250>1.960)$, oleh karena itu hipotesis nol bahwa regression weight sama dengan nol dapat ditolak dan hal ini berarti pengaruh kepuasan merek terhadap sikap loyalitas signifikan, sehingga hipotesis ketujuh yang menyatakan kepuasan merek memiliki pengaruh signifikan terhadap sikap loyalitas pelanggan hotel bintang tiga di Tegal diterima.

Berdasarkan pada pengujian kesesuaian dan pengujian statistic yang telah 
dilakukan, model dalam penelitian ini secara keseluruhan tidak dapat dikategorikan sebagai very good fit models, tetapi masuk pada kategori adequate fit model. Hal ini terjadi karena nilai yang menjadi kriteria untuk mengevaluasi pengujian kesesuaian dan pengujian statistik bervariasi dan model statistik ada yang tidak terpenuhi dan hanya mendekati nilai yang diperlukan selama pengujian.

Very good model fit yang tidak dapat dihasilkan dalam penelitian ini disebabkan oleh beberapa masalah, termasuk penggunaan model yang kurang baik atau perbedaan data yang sangat tinggi, baik data seluruh variabel maupun data per variabel, atau keanekaragaman latar belakang responden dalam menjawab pertanyaan.

H1: Pelayanan staff memiliki pengaruh signifikan pada kepuasan merek pelanggan hotel bintang tiga di Tegal.

Hipotesis 1 menyatakan bahwa pelayanan staff memiliki pengaruh signifikan pada kepuasan merek pelanggan hotel bintang tiga di Tegal. Berdasarkan hasil analisis dapat dilihat bahwa pelayanan staff memiliki pengaruh positif pada kepuasan merek pelanggan hotel bintang tiga di Tegal.

Hal ini dapat dilihat dari jumlah responden yang menilai pelayanan staff dari hotel bintang tiga di Tegal adalah memuaskan dan cukup baik sehingga sesuai dengan merek hotel bintang tiga. Ini dikonfirmasi ketika hubungan antara pelayanan staff dengan kepuasan merek menunjukkan hubungan positif di tiga konstruk ekuitas merek berdasarkan-pelanggan.

Hasil penelitian ini menunjukkkan hasil yang sama dengan penelitian sebelumnya yang dilakukan oleh Ahmad and Hashim (2011) yang berjudul “Customer's Brand Equity and Customer Loyalty: A Study on Hotel's Conference Market".

$\mathrm{H} 2$ : Pelayanan staff memiliki pengaruh signifikan terhadap sikap loyalitas pelanggan hotel bintang tiga di Tegal.

Hipotesis 2 menyatakan bahwa pelayanan staff memiliki pengaruh signifikan terhadap sikap loyalitas hotel bintang tiga di Tegal. Berdasarkan pada hasil analisis dapat dilihat bahwa pelayanan staff memiliki pengaruh positif terhadap sikap loyalitas pelanggan hotel bintang tiga di Tegal.

Dari penemuan tersebut, dapat dipahami bahwa dalam customer-based brand equity, pelayanan staff termasuk aspek dalam memahami loyalitas pelanggan. Hasil penelitian ini juga konsisten dengan penelitian yang dilakukan oleh Ahmad dan Hashim (2011).

H3: Citra-diri memiliki pengaruh signifikan terhadap kepuasan merek pelanggan hotel bintang tiga di Tegal. 
Hipotesis 3 menyatakan bahwa citradiri memiliki pengaruh signifikan terhadap kepuasan merek pelanggan hotel bintang tiga di Tegal. Berdasarkan pada hasil analisis dapat dilihat bahwa citra-diri memiliki pengaruh positif terhadap kepuasan merek pelanggan hotel bintang tiga di Tegal.

Hasil dari penelitian ini memberikan dukungan untuk hubungan yang kuat antara kesesuaian citra-diri dengan kepuasan. Yaitu, kesesuaian citra-diri dapat dipertimbangkan sebagai prediktor yang kuat dari kepuasan dalam industri hotel. Dengan demikian, penemuan ini selaras dengan yang dilaporkan oleh Ahmad dan Hashim (2011), yang melaporkan penemuan yang sama dalam hotel conference market.

H4: Citra-diri memiliki pengaruh signifikan terhadap sikap loyalitas pelanggan hotel bintang tiga di Tegal.

Hipotesis 4 menyatakan bahwa citra diri memiliki penagruh signifikan terhadap sikap loyalitas pelanggan hotel bintang tiga di Tegal. Berdasarkan pada hasil analisis dapat dilihat bahwa citra-diri memiliki pengaruh positif terhadap sikap loyalitas pelanggan hotel bintang tiga di Tegal.

Kesesuaian citra-diri telah memainkan peranan penting dalam menyampaikan a fine-grained picture dari formasi loyalitas pelanggan hotel bintang tiga dalam model teoritis. Hal ini tidaklah mengherankan, dinilai dari fakta bahwa semua tipologi citra-diri didasarkan pada persepsi terhadap atribut dan daya tarik yang tersedia dalam suatu tujuan. Selain itu, "paket loyalitas" dari berbagai operator wisata dan upaya pemerintah dalam berbagai kampanye berpengaruh pada daya tarik ke arah ideal dan citra-diri. Temuan dalam penelitian ini mengintegrasikan karya terbaru tentang kesesuaian citra-diri ke dalam isi penelitian yang sedang berkembang mengenai peran kepuasan pelanggan hotel bintang tiga dalam membentuk loyalitas pelanggan.

Hasil penelitian ini menunjukkan hasil yang sama dengan penelitian yang dilakukan oleh Abdallat dan El-Emam (2002)

H5: Kesadaran merek memiliki pengaruh signifikan terhadap kepuasan merek pelanggan hotel bintang tiga di Tegal.

Hipotesis 5 menyatakan bahwa kesadaran merek memiliki pengaruh signifikan terhadap kepuasan merek pelanggan hotel bintang tiga di Tegal. Berdasarkan pada hasil analisis dapat dilihat bahwa kesadaran merek memiliki pengaruh positif terhadap kepuasan merek pelanggan hotel bintang tiga di Tegal. 
Menurut hasil statistik, kesadaran merek dimuat secara signifikan sebagai faktor ekuitas merek berbasis-pelanggan untuk hotel bintang tiga. Kesadaran merek juga merupakan faktor kritis untuk ekuitas merek (sebagai sebuah tugas kunci manajemen merek untuk memperoleh merek dalam pertimbangan-pertimbangan target konsumen). Hasil ini konsisten dengan penelitian Ahmad dan Hashim (2011).

H6: Kesadaran merek memiliki pengaruh signifikan terhadap sikap loyalitas pelanggan hotel bintang tiga di Tegal.

Hipotesis 6 menyatakan bahwa kesadaran merek memiliki pengaruh signifikan terhadap sikap loyalitas pelanggan hotel bintang tiga di Tegal. Berdasarkan pada hasil analisis ini dapat dilihat bahwa kesadaran merek memiliki pengaruh positif terhadap sikap loyalitas pelanggan hotel bintang tiga di Tegal.

Berdasarkan pada hasil, industri perhotelan seharusnya banyak memperhatikan pada pengaruh kesadaran merek terhadap loyalitas.

H7: Kepuasan merek memiliki pengaruh signifikan terhadap sikap loyalitas pelanggan hotel bintang tiga di Tegal.

Hipotesis 7 menyatakan bahwa kepuasan merek memiliki pengaruh signifikan terhadap sikap loyalitas pelanggan hotel bintang tiga di Tegal. Berdassarkan pada hasil analisis dapat dilihat bahwa kepuasan merek memiliki pengaruh positif terhadap sikap loyalitas pelanggan hotel bintang tiga di Tegal.

Penemuan tersebut membangun peranan mediasi dari kepuasan merek dalam hubungan kepuasan-loyalitas. Hal ini menunjukkan bahwa untuk memastikan sikap loyalitas yang baik dari pelanggan, hotel bintang tiga perlu mendapatkan kepuasan merek terlebih dahulu.

\section{Kesimpulan dan Saran}

Berdasarkan pada hasil penelitian yang telah dibahas sebelumnya, maka dapat disimpulkan sebagai berikut:

1. Pelayanan staff memiliki pengaruh signifikan terhadap kepuasan merek pelanggan hotel bintang tiga di Tegal.

2. Pelayanan staff memiliki pengaruh signifikan terhadap sikap loyalitas pelanggan hotel bintang tiga di Tegal.

3. Kesesuaian citra-diri memiliki pengaruh signifikan terhadap kepuasan merek pelanggan hotel bintang tiga di Tegal.

4. Kesesuaian citra-diri memiliki pengaruh signifikan terhadap sikap loyalitas pelanggan hotel bintang tiga di Tegal.

5. Kesadaran merek memiliki pengaruh signifikan terhadap kepuasan merek pelanggan hotel bintang tiga di Tegal. 
6. Kesadaran merek memiliki pengaruh signifikan terhadap sikap loyalitas pelanggan hotel bintang tiga di Tegal.

7. Kepuasan merek memiliki pengaruh signifikan terhadap sikap loyalitas pelanggan hotel bintang tiga di Tegal.

Berdasarkan pada temuan-temuan penelitian, ada beberapa implikasi manajerial yang disarankan bagi manajer hotel bintang tiga di Tegal untuk meningkatkan customer-based brand equity (CBBE), termasuk:

Hasil penelitian ini menunjukkan bahwa pelayanan staff memiliki pengaruh pada kepuasan merek dan sikap loyalitas, oleh karena itu hotel bintang tiga di Tegal seharusnya dapat memperbaiki pelayanan staff supaya berkontribusi terhadap kepuasan pelanggan hotel dengan ekuitas merek hotel yang mengarah pada loyalitas merek. Untuk memperbaiki pelayanan staff, manajer hotels harus memberikan pelatihan kepada staff setiap enam bulan atau setahun sehingga staff mengetahui bagaimana melayani pelanggan hotel khususnya berkaitan dengan sikap, keterampilan, pengetahuan dan kebiasaan staff. Sikap berarti tidak hanya "dedikasi" terhadap pekerjaan tetapi juga mencintai hidup dan berfikir positif, optimis, and ceria. Keterampilan mengacu pada keterampilan teknis dan pelayanan. Pengeta- huan paling tidak harus komprehensif. Kebiasaan berarti bahwa staffs akan mengembangkan kebiasaan yang baik di setiap aspek ketika bersama dengan yang lain. Selain itu, manajer harus memilih orang-orang yang tepat ketika melakukan perekrutan khususnya yang kompeten dan memiliki pengetahuan mengenai hotel.

Hasil penelitian ini menunjukkan bahwa kesesuaian citra-diri memiliki pengaruh pada kepuasan merek dan sikap loyalitas, oleh karena itu hotel bintang tiga di Tegal seharusnya dapat memposisikan hotel mereka karena kesesuaian citra-diri dapat memperkuat merek hotel yang dihubungkan dengan citra pelanggan, yang pada akhirnya mengarah pada kepuasan merek dan loyalitas merek. Manajer hotel dapat mengembangkan pesan iklan yang dapat mendorong pelanggan untuk berfikir tentang citra-diri mereka karena iklan yang sesuai dengan citra-diri pelanggan lebih efektif. Selain itu, jika target pemasaran menunjukkan bahwa sifat kepribadian utama adalah yang terbaru, manajer harus dapat membuat atau memodifikasi citra mereka ke arah target pelanggan mereka dengan mengembangkan iklan yang menampilkan tata letak perabotan, warna, dan logo yang moderen. Misalnya, Fairfield Inn mengubah logo sebelumnya menjadi logo merek yang baru karena menemukan bahwa logo sebelumnya 
menyiratkan citra konservatif, sedangkan citra ideal target pasar utamanya adalah lebih moderen.

Hasil penelitian ini menunjukkan bahwa kesadaran merek memiliki pengaruh pada kepuasan merek dan sikap loyalitas, oleh karena itu hotel bintang tiga seharusnya dapat meningkatkan ekuitas merek hotel mereka sehingga pelanggan mengetahui tentang merek mereka dan meningkatkan kesadaran merek pelanggan yang menyebabkan kepuasan dan loyalitas. Untuk meningkatkan ekuitas merek hotel manajer harus memberikan penetrasi iklan melalui media-media periklanan seperti surat kabar lokal, radio, youtube, media sosial online, dan lain sebagainya supaya orang-orang mengetahui tentang merek hotel. Penelitian ini menyarankan bahwa manajer hotel bintang tiga seharusnya memperhatikan kepada pengaruh kesadaran merek. di samping itu, penelitian lain menemukan bahwa jika pelanggan dapat mengenal nama merek ketika mereka ingin tinggal di hotel, hal tersebut berarti bahwa hotel memegang kesadaran merek yang tinggi. Ketika sebuah hotel memiliki nama merek yang terkenal, hotel tersebut dapat menjadi pilihan pelanggan dan meningkatkan loyalitas mereka. Dengan demikian, industry hotel harus membangun merek dan mempromosikan kesadaran mereknya melalui promosi, iklan, dan kegiatan pemasaran lainnya. Ketika kesadaran merek tinggi, loyalitas mereknya juga akan meningkat.

Hasil penelitian ini menunjukkan bahwa kepuasan merek memiliki pengaruh pada sikap loyalitas, oleh karena itu hotel bintang tiga harus dapat memberi kepuasan melalui seluruh pelayanan hotel kepada pelanggan yang mengarah pada kepuasan merek dan menjadi pelanggan setia (loyal). Manajer harus memberikan kualitas pelayanan dan fitur pelayanan untuk membuat pelanggan puas sebagai tanggapan yang akan membawa loyalitas pelanggan untuk pemilik dan memfasilitasi mereka dalam mengembangkan bisnis mereka. Manajer dalam industri hotel mungkin secara khusus fokus pada hal-hal berikut ini:

Hotel harus memahami kebutuhan pelanggan dan memberikan pelayanan yang sopan serta memenuhi kebutuhan tersebut secara efisien. Karyawan merupakan personel kunci yang membentuk kesan hotel. Oleh karena itu, penampilan mereka harus rapi. Mereka harus berusaha untuk memberikan sentuhan pribadi kepada setiap pelanggan sehingga ada komitmen dengan masing-masing hotel yang langgeng. Pelanggan biasanya lebih menyukai hotel yang memiliki lini produk yang luas, penawaran berkualitas dengan harga yang wajar, dan lokasi yang nyaman. 
Oleh karena itu, manajer harus fokus pada

\section{Daftar Pustaka}

Abdallat, M. M. A., \& El-Emam, H. E.-S. (2002). Self Congruity and The Impact of Customer Satisfaction on Tourist Loyalty. academia.edu.

Ahmad, Z., \& Hashim, R. (2011). Customer's Brand Equity and Customer Loyalty: A Study on Hotel's Conference Market. World Applied Sciences Journal 12(Special Issue of Tourism \& Hospitality), 44-49.

Bailey, R., \& Ball, S. (2006). An Exploration of The Meanings of Hotel Brand Equity. The Service Industries Journal, 26(1), 15-38. doi: 10.1080/02642060500358761

Ferdinand, A. (2002). Structural Equation Modeling Dalam Penelitian Manajemen. Semarang: Badan Penerbit Universitas Diponegoro.

Gold, M. (Producer). (2005). What Inspires Loyalty Today? Retrieved from

https://www.thecaterer.com/articles B02948/what-inspires-loyaltytoday

Kandampully, J., \& Suhartanto, D. (2000). Customer Loyalty in The Hotel Industry: The Role of Customer Satisfaction and Image. faktor-faktor ini.

$$
\begin{aligned}
& \text { International Journal of } \\
& \text { Contemporary Hospitality } \\
& \text { Management, 12(6), 346-351. doi: } \\
& \text { https://doi.org/10.1108/095961100 } \\
& 10342559
\end{aligned}
$$

Kim, H.-b., \& Kim, W. G. (2005). The Relationship Beetween Brand Equity and Firms' Performance in Luxury Hotels and Chain Restaurants. Tourism Management, 26, 549-560. doi: 10.1016/j.tourman.2004.03.010

Liang, D. (2008). The Determining Factors of Customer Loyalty for Luxury Hotels in US. The Journal of International Management Studies, 3(2), 167-175.

O'Neill, J. W., \& Matilla, A. S. (2004). Hotel Branding Strategy: Its Relationship to Guest Satisfaction and Room Revenue. Journal of Hospitality \& Tourism Research, 28(2), 156-165. doi: $10.1177 / 1096348004264081$

Sangster, A., Wolton, J., \& Day, M. (2001). The International Hotel Industry. London: Travel \& Tourism Intelligence.

Umar, H. (2008). Metode Penelitian untuk Skripsi dan Tesis Bisnis. Jakarta: PT RajaGrafindo Persada. 